\title{
Word order in Latin locative constructions: A corpus study in CAESAR's De bello gallico
}

\begin{abstract}
Classical Latin is a free word order language, i.e., the order of the constituents is determined by information structure rather than by syntactic rules. This article presents a corpus study on the word order of locative constructions and shows that the choice between a Theme-first and a Locative-first order is influenced by the discourse status of the referents. Furthermore, the corpus findings reveal a striking impact of the syntactic construction: complements of motion verbs do not have the same ordering preferences with complements of static verbs and adjuncts. This finding supports the view that the influence of discourse status on word order is indirect, i.e., it is mediated by information structural domains.
\end{abstract}

\section{Preliminaries}

Locative constructions are semantic-syntactic configurations that express the localization of a referent in space, see, e.g., (1). By definition, locative constructions involve a 'localized object', which is expressed through the theme constituent tenth legion in (1), and an expression denoting the localization of this referent. The localization is expressed by the locative constituent in (1), which specifies a domain of the three-dimensional space. This domain is determined by the spatial region encoded through the preposition in of a 'reference object', which is expressed through the prepositional complement Noviodunum in (1) (see JACKENDOFF 1983: 161, KLEIN 1991: 78, LEHMANN 1983: 146, 1992: 627, LEVINSON 2003; TALMY 2000: 311).

\section{(1) The tenth legion was in Noviodunum.}

The word order properties of these constructions have been the subject of several empirical studies in corpora (BIRNER 1994) as well as in language production (HÖRNIG and FÉRY 2009, FÉRY, SKOPETEAS and HÖRNIG 2010) and comprehension (see an overview in HÖRNIG and WESKOTT 2010). Under particular discourse conditions, locative constructions appear in a marked word order in which the locative constituent precedes the theme, as illustrated in (2a-b). This construction is termed 'locative inversion', a term that makes sense in languages such as English or French, in which the reordering of the arguments is restricted to particular constructions. The discourse conditions that license this construction differ across languages (see BRESNAN 1994 on English and Chichewa; FÉRY, HÖRNIG and SKOPETEAS 2010 on English, Finnish, French, Georgian, German, and Mandarin Chinese). In English, this word order is typically licensed in a context in which the referent of the locative constituent is in presentational focus (see 
discussion BIRNER 1994: 236ff.), which is possible in (2a). This reading is excluded in (2b), since the theme constituent is part of the presupposed information (as indicated by the definiteness of the theme). This example is licit in a context in which the postverbal theme constituent is contrasted to other relevant alternatives that are available in the context (see BIRNER 1994: 238 for similar examples). However, empirical findings in English show that cases such as (2b) rarely occur in corpus, since the majority of instances of locative inversion involve a discoursenew theme referent (674 out of 703, i.e., 95.8\%, see BIRNER 1994: 244).

(2) a. In Noviodunum was a portion of the tenth legion.

b. In Noviodunum was the tenth legion.

Beyond the influence of the discourse properties of the referents, it has been observed that the properties of the verbal head have a crucial contribution to the licensing of the inverted order of locative constructions. The first relevant factor relates to the government of the locative constituent by the verbal head: locative complements allow for inverted word order in more contexts than locative adjuncts (see BRESNAN 1994: 75-77, 82f.), which may be accounted for as a difference in the structural positions of locative arguments and locative adjuncts (REINHART 1983: 68-72). The second factor relates to the informational contribution of the verbal head: verbs that do not have an essential contribution to the asserted information - either because they do not contribute to the propositional content (cf. the verb $b e$ ) or because they present evoked or inferrable information in context are more frequently found in sentences with inverted word order (see BIRNER 1994: 254, 1995).

Aim of the present article is to examine how the properties of the verb interact with the discourse properties of the referents in the licensing of marked word orders of locative constructions in a language with flexible word order, namely in Classical Latin. Since Classical Latin is the textbook example of a flexible word order language, we expect to observe the pure effect of discourse properties on word order. Section 2 outlines the properties of Latin word order. Section 3 introduces the empirical basis of the present article, which is a corpus study on CAESAR's De bello gallico. Section 4 presents the empirical findings of this study and discusses their relevance for understanding the word order of locative constructions.

\section{Latin word order}

It is frequently observed that word order in Latin is 'free', which means that all permutations of basic constituents are attested and that the frequency of the possible orders in texts does not allow for clear conclusions about the predominant pattern. Word order variation in discourse is determined by non-syntactic factors such as information structure, constituent weight, etc. These phenomena motivate 
the generalization that word order in Latin is essentially determined by pragmatics (see PANHUIS 1982, PINKSTER 1990a).

Taken for granted that the observed variation is determined by non-syntactic factors, the question is whether there are ordering preferences beyond the impact of these factors, i.e., a word order configuration that is more likely to occur across contexts. There is a clear preference for the subject to precede the predicate (see CHARPIN 1977: 423; DE JONG 1989: 536; KÜHNER and STEGMANN 1976: 590; DEVINE and STEPHENS 2006: 37-40). The order within the predicate is generally assumed to be OV in the Classical era (see GREEN 1908/1909: 10; KÜHNER and STEGMANN 1976: 590; RUBENBAUER and HOFMANN 1995: 326; MENGE 2005: 575; BAUER 2009: 268) and to changing into VO in a later diachronic stage. ${ }^{1}$ The main evidence for this claim comes from the frequency of these two orders in the diachronic corpus. Based on the counts of small-size text samples reported in PINKSTER (1990a: 72) (see also MAROUZEAU 1938: 47), we observe that SOV is more frequent than SVO in the authors of the $1^{\text {st }}$ century BC and the $1^{\text {st }}$ century AC $(100 \%$ of the examined SOV+SVO tokens in CICERO, $94.2 \%$ in CAESAR, $63.6 \%$ in VITRUVIUS, $92.7 \%$ in CELSUS, $70.8 \%$ in PETRONIUS), while the relative frequency of SOV generally reduces in texts from the $2^{\text {nd }}$ to $4^{\text {th }}$ century AC $(23.1 \%$ of the examined $\mathrm{SOV}+\mathrm{SVO}$ tokens in ClaUdiUs TeRENTIANUS, $50 \%$ in Passio Sanctorum Scilitanorum, 38.6\% in Peregrinatio, 65.2\% in Vulgata).

Some variation is also observed in Classical Latin which probably suggests the co-existence of a progressive and a conservative register, and a stronger preference for V-final configurations in the latter (see LINDE 1923, ADAMS 1976: 94-97; PINKSTER 1990). Prescriptive norms indicated that the V-final order had to be preferred. ${ }^{2}$ CAESAR's language certainly belongs to the conservative paradigm and shows a strong preference for V-final configurations (see ADAMS 1976: 94; MAROUZEAU 1938: 48). PINKSTER (1990a: 72) reports the proportions of word orders in a sample of 568 sentences with the three basic constituents in CAESAR: the majority of tokens is V-final ( $63.4 \% \mathrm{SOV}$ and $21.1 \% \mathrm{OSV})$, while V-medial and V-initial tokens are less frequent $(3.9 \% \mathrm{SVO}, 5.8 \% \mathrm{OVS}, 1.1 \% \mathrm{VSO}$, and $4.8 \%$ VOS). The predominance of SOV in CAESAR is evidence for SOV word order under the assumption that this pattern results from the fact that this order is contextually unrestricted, while the deviating orders require a licensing condition in the context.

\footnotetext{
${ }^{1}$ Dating the OV-to-VO change in the history of Latin is a matter of dispute. Some authors assume that Late Latin already turns to VO from the $4^{\text {th }}$ century AC (see LINDE 1923) or even in the progressive registers of the Classical era (ADAMs 1976: 72). However, Koll (1965: 246f.) reports that the OV orders are still found with considerable frequency in the texts of the Merovingian and Carolingian period.

2 "If the demands of artistic structure permit, it is far best to end the sentence with a verb: for it is in verbs that the real strength of language resides." (QUINTILIANUS, Institutio oratoria 9.4.26, transl. by H.E. BuTLER, Loeb Classical Library edition).
} 
Further properties of the Latin word order show that VPs in Latin are headfinal. ${ }^{3}$ Within the verb complex, auxiliaries generally follow the lexical verb, see illustration in (3a). In verb-to-verb dependencies, the dependent verb (infinitive) precedes the verbal head (finite verb) more frequently than not, see illustration in $(3 b)$.

(3) a. ... reliqui in oppidum reiecti sunt.

'the rest were forced back into the town' (CAESAR, De bello gallico, II.33)

b. Hi neque vultum fingere neque interdum lacrimas tenere poterant.

'These could neither compose their countenance, nor even sometimes check their tears' (CAESAR, De bello gallico, I.39)

The V-final order occurs more frequently in subordinate clauses than in main clauses, see illustrative example in (4) (see LINDE 1923, KOLL 1965: 245, PINKSTER 1990a: 69; 1990b: 169, HOFFMANN and SZANTYR 1965 with particular reference to CAESAR). This observation is relevant for the question of canonical word order under the assumption that information structural configurations (such as topicalization and focusing) that license marked word orders are more likely to occur in main clauses than in subordinate ones, since the latter frequently present presupposed information (see discussion of this hypothesis in Latin in MAROUZEAU 1938: 49, BOLKESTEIN 1989: 31).
...flumine Rheno latissimo atque altissimo, qui agrum Helvetium a Germanis dividit.
'by the Rhine, a very broad and deep river, which separates the Helvetian territory from the Germans' (CAESAR, De bello gallico, I.2)

Finally, Latin displays some constructions that are characteristic of V-final languages. For instance, in case of coordinated sentences sharing the same verb, the verb most frequently appears in the second conjunct, see illustrative examples in (5) (see PANHUIS 1980: 231f., ELERICK 1989: 566). This property is in line with V-final languages such as Japanese and in contrast to V-initial languages such as English (see Ross 1970), in which the verb appears in the first conjunct and is gapped in the second. Latin also exhibits some cases of gapping in the first conjunct, however these cases occur under the conditions that apply for $\mathrm{V}$-fronting in general, e.g., sentences with the verb esse 'to be' (see discussion below).

\footnotetext{
${ }^{3}$ We do not consider evidence for head finality in other types of constituents since these observations are only relevant under the assumption that the head-directionality in different types of syntactic projections is uniform, which is not the case (see discussion of the diachronic correlation of the headdirectionality of several constructions in ADAMS 1976).
} 
(5) Gallos ab Aquitanis Garumna flumen, a Belgis Matrona et Sequana dividit. 'The river Garonne separates the Gauls from the Aquitani, the Marne and the Seine separate them from the Belgae.' (CAESAR, De bello gallico, I.1)

Deviations from the SOV order depend on particular licensing conditions. Two different types of such deviations are illustrated in (6). The verb esse 'to be' frequently appears in non-final position, see (6) (see GREEN 1908/1909: 10; counts from CAESAR and CICERO in WALKER 1918: 654). This peculiarity may be due to phonological reasons, i.e. this verb cliticizes at the first accented word within the clause (see KOLL 1965: 245, 247, KÜHNER and STEGMANN 1976: 602; RUBENBAUER and HOFMANN 1995: 326, BAUER 2009: 296).

(6) Gallia est omnis divisa in partes tres, quarum unam incolunt Belgae, aliam Aquitani, tertiam qui ipsorum lingua Celtae, nostra Galli appellantur.

'All Gaul is divided into three parts, one of which the Belgae inhabit, the Aquitani another, those who in their own language are called Celts, in ours Gauls, the third.' (CAESAR, De bello gallico, I.1)

Another subset of deviations from the V-final order is due to contextual licensing. It is generally assumed that word order has an essential role in the expression of information structure in Latin, since this language lacks a definite article and makes less use of particles than Ancient Greek or German. ${ }^{4}$ Frame setters and topic constituents occur sentence initially (see PINKSTER 1990a: 75, 1990b: 172; SOMERS 1991: 153-158; MENGE 2005: 576; SPEVAK 2010: 15). Example (7a) illustrates an instance of non-canonical word order, in which a PP containing an anaphoric constituent is fronted to the sentence-initial position. Fronting is also used for contrastive topics, i.e., constituents that introduce a topic contrasting to a contextually available alternative referent, see (5) above. Background information appears after the verb as illustrated by (7b) (see TOURATIER 1994: 342).

(7) a. Context: 'that it was better for them, if they should be reduced to that state, to suffer any fate from the Roman people, than to be tortured to death by those among whom they had been accustomed to rule.'

Ad haec Caesar respondit:

'To these things Caesar answered: ...' (CAESAR, De bello gallico, II.32)

b. Non minus qui intra munitiones erant perturbantur Galli...

'The Gauls, who were within the fortifications, were no less panicstricken ...' (CAESAR, De bello gallico, VII.70)

\footnotetext{
${ }^{4}$ Cf. argumentation in LEHMANN (1979: 242-244); evidence showing the interaction of definiteness and word order in RosÉn (1991: 137f.).
} 
Focus is realized in Latin word order with great variation, which can only be explained if we assume a rich prosody differentiating between the alternative options (see LEHMANN 1979: 243). Latin shares with many V-final languages the preference for the placement of the focused constituent in the preverbal position (see DEVINE and STEPHENS 2006: 88), which is complementary to the fact that out-of-focus material is either placed in the sentence-initial domain (as in (7a)) or occurs postverbally. Another possibility is to express the focus in the postverbal domain (see KÜHNER and STEGMANN 1976: 592; RUBENBAUER and HOFMANN 1995: 326, MENGE 2005: 576; PINKSTER 1990b: 169, 179f.). For instance, negative quantifiers can be placed postverbally, as illustrated in (8) (see also discussion of the properties of negative quantifiers in DEVINE and STEPHENS 2006: 173ff.). Furthermore, postverbal subjects may bear the focus of the clause (KÜHNER and STEGMANN 1976: 597- 598; DE JONG 1989: 531-536).

... propterea quod illo licente contra liceri audeat nemo.

'... because when he bids, no one dares to bid against him.' (CAESAR, De bello gallico, I.18)

A further option is to realize the focus constituent sentence-initially (see GREEN 1908/1909: 2; KÜHNER and STEGMANN 1976: 591; RUBENBAUER and HOFMANN 1995: 326; Menge 2005: 576; SPEVAK 2010: 41). The different options for the expression of focus may correlate with different focus types: while the preverbal focus is an unspecified focus strategy (for all focus types) and the typical way to encode new information focus, contrastive focus is frequently expressed in situ (without any effect on word order) or fronted to the initial position (DEVINE and STEPHENS 2006: 232).

Sentence-initial placement of the verb occurs under restricted conditions (see MENGE 2005: 576; BAUER 2006: 275-279). For instance, the verb occurs at the beginning of the clause in presentational sentences that are used to introduce new referents at the beginning of a discourse unit and in sentences involving verb focus (GREEN 1908/1909: 10; MAROUZEAU 1938: 50; KÜHNER and STEGMANN 1976: 599-601; LURAGHI 1995; BAUER 2006: 278; SPEVAK 2010: 57).

Beyond the influence of contextual factors, word order may also be influenced by the constituent weight, i.e., there is a preference for heavy constituents to occur late in the utterance (see BOLKESTEIN 1989: 23ff.; PINKSTER 1990b: 168; BAUER 2009: 299-302). Finally, purely stylistic reasons may influence word order as well, e.g. avoidance of chiasmus (GREEN 1908/1909: 10; KÜHNER and STEGMANN 1976: 621), rhythmical preferences (DEL VECCHIO 1989: 546-551), distinctness constraints banning sequences of nouns with identical case endings (see CHARPIN 1989: 510), etc.

Summing up, Classical Latin displays a register-specific OV/VO variation, whereby CAESAR's text belongs to the OV variety. Deviations from the final placement of the verb are due to structural factors (fronting phonologically light verbs to the WACKERNAGEL's position, right extraposition of heavy constituents) 
or due to information structural factors (V-initial sentences in presentational contexts, postverbal placement of background or focused information). Focus placement in Latin is more flexible than in other V-final languages. It may occur sentence-initially and without being adjacent to the verb (unlike V-final languages such as Georgian, see SKOPETEAS and FANSELOW 2009, and Basque, see ARREGI 2001), or left-adjacent to the verb (which is the preferred option for V-final languages) or even postverbally (which is not possible in Turkish, see KILIÇASLAN 2004, and Basque, see ARREGI 2001).

\section{Method}

The aim of the corpus study reported in the following is to identify correlations between word order and context in Latin. Confirming evidence for the hypothesis that particular properties of word order are licensed by certain contexts is the increase of the conditional probability of a particular order in the hypothesized context in comparison to the conditional probability of the same order in the possible alternative context(s). This approach implies that the relation between orders and contexts is not $1: 1$, which is motivated by the observation that the context is not the only factor that determines the choice of word order in Latin prose, further relevant factors being stylistic, rhythmical, etc. preferences (see discussion in Section 2). These factors are independent of the context, hence if the conditional probability of a particular word order is significantly higher in context $C_{1}$ than in context $C_{2}$, we assume that this difference reflects the genuine impact of the context and that the effects of the non-contextual factors are counterbalanced in the sample of observations. ${ }^{5}$

\subsection{Text sample}

The text sample of this study contains the books I-VII of CAESAR's De bello gallico. This text is a narrative of historical interest, reporting the battles that the Romans conducted in Gaul between 58 and 52 BC. CAESAR wrote these books after the end of the war (52-51 BC), while the eighth and last book is written by AULIUS HIRTIUS and for this reason is excluded from the present sample. This text is appropriate for the study of locative constructions since it contains a large number of spatial descriptions, e.g., in the reports of military arrangements or movements during the battle or in geographical descriptions of the places in which the historical events took place. The main aim of the author is the simple and precise exposition of the historical events rather than the literary value, which is reflected in the structural simplicity of the expression (see SCHLICHER 1936). The language of CAESAR belongs to the conservative register of Classical Latin,

\footnotetext{
${ }^{5}$ The adopted measure of truth is the $p$ value $(<.05)$ of Pearson's chi-square test; whenever the conditions for the application of this test are not met, we rely on the results of Fisher's Exact Test.
} 
influenced by the language of the orators and the purist attitudes of its era in writing (see ADAMS 1976: 94, ALBRECHT 1994: 334).

The books I-VII of De bello gallico include 346 paragraphs according to the numeration of the text edition, which contain 2538 periods determined by the punctuation (44268 words). The whole text is dealt with as a uniform sample, since the stylistic variation between the individual books does not interfere with the hypotheses at issue. ${ }^{6}$

\subsection{Valid data}

The question is which factors determine the order between the theme and the locative constituent of a locative construction. For this purpose, we considered declarative sentences involving a subject constituent, a locative constituent, and a finite verbal head. Hence, we excluded expressions of the localization of direct objects, i.e., constructions with active verbs of transport such as trädücere 'to bring across' such as (9a) (287 tokens found in the sample), sentences without subject constituent such as (9b) (14 tokens), and utterances in which the subject is not realized as a syntactic constituent (though encoded through the person affixes), see (9c) and (9d) (360 tokens). Example (9c) illustrates the case that the subject is not realized as a constituent since it can be retrieved from the context. Corpus findings in other languages show that this configuration is the most frequent case in discourse, since subjects are very frequently discourse topics. ${ }^{7}$ Example (9d) illustrates an instance of VP coordination with a locative construction in the nonfirst conjunct. These clauses involve a lexically realized subject, but they are not informative for our purposes, since at the critical moment that the speaker produces the locative construction, which is in the second conjunct in (9d), he does not have the choice between alternative orders of the subject and the locative constituent.

(9) a. Helvetii iam per angustias et fines Sequanorum suas copias traduxerant, ...

'The Helvetii had already led their forces over through the narrow defile and the territories of the Sequani, ...' (CAESAR, De bello gallico, I.11)

b. Acriter in eo loco pugnatum est.

'There was a severe struggle in that place.' (CAESAR, De bello gallico, II.10)

c. Post eius mortem nihilo minus Helvetii id quod constituerant facere conantur, ut e finibus suis exeant.

\footnotetext{
${ }^{6}$ See SCHLICHER (1936) about the differences in the complexity of sentential forms in the individual books and their relation to the narrative style.

${ }^{7}$ For instance, Du BoIs (1987: 819) reports that the $48.1 \%$ of occurrences of intransitive verbs in a text sample from Sacapultec Maya does not have a subject constituent.
} 
'After his death, the Helvetii nevertheless attempt to do that which they had resolved on, namely, to go forth from their territories.' (CAESAR, De bello gallico, I.5)

d. reliqui sese fugae mandarunt atque in proximas silvas abdiderunt.

'The rest betook themselves to flight, and concealed themselves in the nearest woods.' (CAESAR, De bello gallico, I.12)

The valid data contains locative constituents with a spatial PP or a local case (accusative encoding the target of motion or ablative encoding either origin or static location), which excludes cases in which a spatial region is encoded through an adjective such as (10a), that involve a different syntactic structure. The valid data set includes only these tokens in which the locative constituent depends on a finite verbal head, which excludes utterances with a non-verbal head, see (10b), utterances without an overt verbal head, see the first conjunct of (5) above, and utterances with a non-finite verbal head, see the present participle in (10c).

(10) a. P. Crassus adulescens eum legione VII. proximus mare Oceanum in Andibus hiemabat.

'P. Crassus, a young man, had taken up his winter quarters with the seventh legion near the ocean among the Andes.' (CAESAR, De bello gallico, III.7.2)

b. $\quad$... dicerent sibi esse in animo sine ullo maleficio iter per provinciam facere.

'...they say that it was their intention to march through the Province without doing any harm.' (CAESAR, De bello gallico, I.7)

c. ... discedens ab hibernis Caesar in Italiam ...

'...when Caesar was departing from his winter quarters into Italy, ...' (CAESAR, De bello gallico, V.1)

We further excluded relative clauses, introduced by a relative pronoun either in the thematic role of the theme, as in (11a) (108 tokens), or in the thematic role of the locative (64 tokens), as in (11b). The choice of order in this case does not interact with contextual factors, since the position of the relative pronoun is structurally determined. Relative clauses with a relative pronoun in the thematic role of the theme are more frequent than relative clauses with the thematic role of the locative.

(11) a. ...pontem, qui erat ad Genavam, ...

'... the bridge that was at Geneva, ...' (CAESAR, De bello gallico, I.7)

b. ... civitates propinquae iis locis erant ubi bellum gesserat, ...

'... the states were close to those regions in which he had waged war...' (CAESAR, De bello gallico, II.35) 


\subsection{Decoding}

The remaining valid data for the examination of the word order properties of locative constructions contains 338 clauses. These tokens have been decoded for (a) word order (six permutations of a V, a theme, and a locative); (b) clause type (main, subordinate); (c) syntactic construction (complement of static verb; complement of motion verb; adjunct); (d) discourse status of the participants (new, given).

WORD ORDER. Six word order permutations are possible in sentences with a verb (V), a theme constituent (The), and a locative constituent (Loc): TheLocV, LocTheV, TheVLoc, LocVThe, VTheLoc, VLocThe. A problem for the annotation of word order is the frequent occurrence of discontinuous constituents in Latin (see BAUER 2009: 286-292 with particular reference to CAESAR; see also DEVINE and STEPHENS 2006: 531-542). In decoding of word order in these cases was based on the head subconstituents. For instance, the utterance in (12) has the order TheLocV, since the head of the theme constituent precedes the locative constituent.

(12) at equites Aedui ad Caesarem omnes revertuntur.

'but the Aeduan horsemen all return to Caesar.' (CAESAR, De bello gallico, V.7)

CLAUSE TYPE. The difference between main and subordinate clauses is relevant for observations on word order, since we know that subordinate sentences show a stronger preference for clause-final placement of the verb in Latin.

SYNTACTIC CONSTRUCTION. In order to observe the influence of the verbal head on the word order, we examine a syntactic and a semantic property. First, we distinguish between verbs that select a locative argument and those that do not. Locative dependents with the latter type of verbs are adjuncts. Second, among verbs with a locative argument we distinguish between static verbs and verbs of motion. These categories give a threefold classification.

Directional locative constituents only occur as dependents of motion verbs in Latin, hence we assume that these constituents are licensed by the verbal head. Examples of motion verbs that are accompanied by a locative complement in our corpus are cōnsìdere 'to sit down', cōnfugere 'to flee', ìre 'to go', trānsīre 'to cross', venìre 'to come', proficīscī 'to depart', profugere 'to escape', revertī 'to turn back', dēscendere 'to descend', ègredī 'to go out', etc. Furthermore, we classified as complements of motion verbs locative constituents that accompany passivized transport verbs such as perferre 'to carry', prōducere 'to bring forth', trädūcere 'to bring across', etc. Directional locative constituents with these verbs have been classified as 'complements of motion verbs'.

Some verbs are used for static local relations and occur very frequently with a static locative constituent in our corpus. We assume that these locative constituents are 'complements of static verbs' (frequency is only an observational measure and not a criterion for government, however it is a useful measure in the lack of 
evidence from speakers' intuitions). The verbs of this class include pertinère 'to extend', remanère 'to remain', incolere 'to inhabit', abesse 'to be away', hiemāre 'to pass the winter', manère 'to remain', morārī 'to stay away', gerere 'to happen', etc.

Further locative constituents are classified as 'adjuncts'. These tokens involve event-external locative adjuncts, that modify the entire clause, as exemplified in (13a) and event-internal locative adjuncts, that modify the verb, as illustrated in (13b).

(13) a. Ibi perpauci aut viribus confisi tranare contenderunt ...

'There some few, either relying on their strength, endeavoured to swim over, ...' (CAESAR, De bello gallico, I.53)

b. in aperto loco secundum flumen paucae stationes equitum videbantur... 'a few troops of horse-soldiers appeared on the open ground, along the river.' (CAESAR, De bello gallico, II.18)

DisCOURSE STATUS. The decoding of the data has been based on a binary concept of contextual givenness. Referents are decoded as 'given' if they are already mentioned within the current thematic unit. As a matter of convention, we divided the seven books of De bello gallico in 16 thematic units, each containing a single expedition or other event described in more than 5 paragraphs. Referents that are not previously mentioned in this unit are decoded as 'new'. This classification does not take into account that a large part of the information that is decoded as 'new' may be assumed to be accessible for the audience of the book or may be inferred from the introduced referents, and hence qualify as 'given' for the hearer. Though this information may be critical for the phenomena at issue, the decoding of observational data with these categories involves controversial assumptions that are avoided here. The empirical data reported in BIRNER (1994: 244) on English inversion shows that the crucial discourse asymmetries can be observed through contextual givenness alone.

\section{Results}

The word order patterns of the 338 critical sentences are presented in Figure 1 (see counts in Table 1), that presents the six possible permutations between a theme, a locative constituent, and a verb. The results reveal two sources of word order variation. First, there is variation in the (initial, medial, final) position of the verb, which may be observed in the differences between the categories at the $x$-axis of Figure 1. The crucial finding is that $\mathrm{V}$-final sentences are significantly more frequent than non-V-final orders $\left(\chi^{2}(1)=418, p<.001\right)$. Second, there is variation in the relative order between the theme and the locative, which may be observed in the difference between the two lines of Figure 1. The Theme-first order is significantly more frequent than the Locative-first order $\left(\chi^{2}(1)=144, p<.001\right)$. 


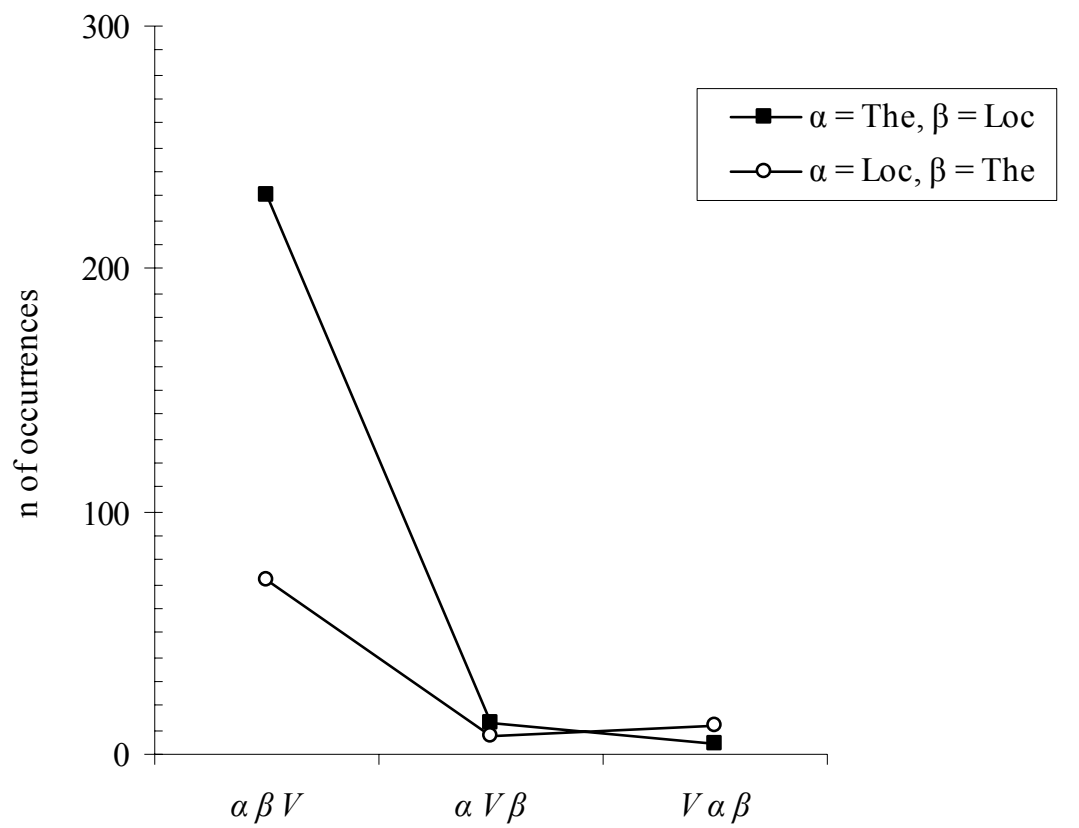

Figure 1. Word order patterns of locative constructions

\begin{tabular}{|l|rr|rr|rr|rr|}
\hline & \multicolumn{2}{|c|}{$\alpha \beta \mathrm{V}$} & \multicolumn{2}{|c|}{$\alpha \mathrm{V} \beta$} & \multicolumn{2}{|c|}{$\mathrm{V} \alpha \beta$} & \multicolumn{2}{|c|}{ Total } \\
& $n$ & $\%$ & $n$ & $\%$ & $n$ & $\%$ & $n$ & $\%$ \\
\hline$\alpha=$ The, $\beta=$ Loc & 230 & 76.2 & 13 & 65 & 4 & 25 & 247 & 73.1 \\
$\alpha=$ Loc, $\beta=$ The & 72 & 23.8 & 7 & 35 & 12 & 75 & 91 & 26.9 \\
\hline Total & 302 & 100 & 20 & 100 & 16 & 100 & 338 & 100 \\
\hline
\end{tabular}

Table 1. Word order patterns of locative constructions

The aim of the following sections is to account for the data pattern in Figure 1. Section 4.1 discusses the factors that determine the position of the verb and accounts for the variation in the $x$-axis of Figure 1. Section 4.2 examines the variation relating to the relative order of themes and locatives and accounts for the differences between the data points in the $y$-axis of Figure 1 .

\subsection{Verb position}

In the majority of the sentences in Figure 1, the verb follows the theme and the locative constituent (302 out 338 tokens, i.e., 89.3\%). The proportion of V-final utterances in our data set is similar to the $84.4 \%$ proportion of transitive clauses with a final V reported in PINKSTER (1990a) (see Section 2). The predominance of the V-final order suggests that it is the default order and that non-V-final clauses occur under restricted licensing conditions. Among the marked options, the $\mathrm{V}$-medial order is the most frequent (20 out 338 tokens, $5.9 \%$ ) which is also in line 
with PINKSTER's observations on transitive clauses (9.1\% SVO+OVS). Finally, the $\mathrm{V}$-initial orders are the least frequent possibility in our dataset (16 out 338 tokens, i.e., 4.7\%) as well as in PINKSTER's (5.9\% VSO+VOS).

Starting from the $16^{\prime} \mathrm{V} \alpha \beta$ ' utterances, we observe that 11 of them are presentational constructions that involve a sentence-initial verb introducing a new referent in the discourse, see (14a). The use of V-initial order in presentational constructions is already observed in several studies on Latin word order (see MENGE 2005: 576; GREEN 1908/1909: 10; MAROUZEAU 1938: 50; KÜHNER and STEGMANN 1976: 599-601, DEVINE and STEPHENS 2006: 150-153). The remaining 5 ' $\mathrm{V} \alpha \beta$ ' utterances involve a verb that, though preceding the theme and the locative, is not sentence initial, see (14b). All five examples contain a light verb that cliticizes to the sentence-initial constituent (see further discussion on this phenomenon below).

(14) a. Context: 'Then stones having been cast from every quarter, the enemy were dislodged, and their tower set on fire.'

Erant in ea legione fortissimi viri, centuriones, qui primis ordinibus appropinquarent, Titus Pullo et Lucius Vorenus.

'In that legion there were two very brave men, centurions, who were now approaching the first ranks, Titus Pullo and Lucius Vorenus.' (CAESAR, De bello gallico, V.44)

b. Opere instituto fit equestre proelium in ea planitie...

'The work having been begun, a cavalry action ensues in that plain...' (CAESAR, De bello gallico, VII.70)

Turning now to the 20 ' $\alpha \mathrm{V} \beta$ ' utterances, we first observe that a subset of these clauses ( 9 tokens) involves the verb esse 'to be', see (15a) (note that the non-final realization of esse is optional, see (15b)). ${ }^{8}$ In this subset of V-medial tokens, we are dealing with a structural factor, i.e., the already observed preference for the verb esse 'to be' to cliticize to the initial constituent of the clause (see Koll 1965: 245, 247, KÜHNER and STEGMANN 1976: 602; RUBENBAUER and HOFMANN 1995: 326, BAUER 2009: 296). Letting aside the V-initial clauses, which are licensed by particular discourse conditions, our dataset of ' $\alpha \mathrm{V} \beta$ ' and ' $\alpha \beta \mathrm{V}$ ' clauses contains 13 occurrences of the existential verb and 309 instances of lexical verbs. In the ' $\alpha \mathrm{V} \beta$ ' configuration, we find 9 of the 13 occurrences of the existential verb $(69.2 \%)$, but only 11 of the 311 occurrences of lexical verbs $(3.5 \%) .{ }^{9}$ This difference is statistically significant, which confirms the hypothesis that the

\footnotetext{
${ }^{8}$ Compare the counts reported for CAESAR in WALKER (1918: 653): a non-V-final order is found in $92.8 \%$ of main clauses with the verb esse and in $10 \%$ of main clauses with lexical verbs.

${ }^{9}$ Compare SpevaK (2010: 191), who reports that $64.7 \%$ out of 34 non-initial locative instances of esse precede either the locative or the theme constituent in a corpus containing samples from CICERO, CAESAR, and SAllust.
} 
existential verb targets an earlier position in the clause $\left(\chi^{2}\right.$ does not apply due to the low expected count in one cell; FISHER's Exact Test gives $p<.001) .{ }^{10}$

(15) a. Tertium est contra septentriones;

'The third side is towards the north.' (CAESAR, De bello gallico, V.13)

b. In eo flumine pons erat.

'Over that river was a bridge.' (CAESAR, De bello gallico, II.5)

The final question is what licenses the remaining 11 tokens of ' $\alpha \mathrm{V} \beta$ ' utterances that involve a lexical verb. In five tokens, the verb is followed by a long constituent, hence the occurrence of postverbal material can be accounted for in terms of the law of growing constituents that is known to apply in Latin, see (16a) (see BOLKESTEIN 1989: 23ff.; PINKSTER 1990b: 168). For the remaining six tokens it can be speculated that the position of the verb is influenced by the information structural configuration, however the low number of observations does not allow us to draw clear conclusions. As an illustration, the postverbal constituent in (16b) presents given information that differs from the current discourse topic and is re-introduced through the utterance. The preverbal locative constituent is contrasted with the locative expression in the subsequent sentence, hence it is plausible to assume that the postverbal subject is part of the background information that follows the focused locative.

(16) a. Usipetes Germani et item Tencteri magna [cum] multitudine hominum flumen Rhenum transierunt, non longe a mari, quo Rhenus influit.

'those Germans [called] the Usipetes, and likewise the Tenchtheri, with a great number of men, crossed the Rhine, not far from the place at which that river discharges itself into the sea.' (CAESAR, De bello gallico, IV.1)

b. Context: 'But Marcus Antonius, and Caius Trebonius, the lieutenants, draughted troops from the redoubts which were more remote, ...'

Dum longius ab munitione aberant Galli, plus multitudine telorum proficiebant; posteaquam propius successerunt, ...

'Whilst the Gauls were at a distance from the fortification, they did more execution, owing to the immense number of their weapons; after they came nearer, ...' (CAESAR, De bello gallico, VII.82)

\footnotetext{
${ }^{10}$ Furthermore, it has been reported that verbs occur less frequently in a fronted position within subordinate clauses (see PINKSTER 1990a: 69; HOFFMANN and SZANTYR 1965 with particular reference to CAESAR): in our dataset, the ' $\alpha \mathrm{V} \beta$ ' order occurs in 5 out of 102 subordinate clauses $(4.9 \%)$ and in 15 out of 220 main clauses $(6.8 \%)$, which is descriptively in line with the previous observations (but statistically not significant according to $\left.\chi^{2}\right)$.
} 
In sum, our data concerning the position of the verb shows a strong preference for head final VPs, which confirms previous observations based on the frequency of V-final sentences in CAESAR (see Section 2). Deviations from the V-final order are licensed by structural or pragmatic factors. A structural factor is the preference for the verb esse 'to be' to occur early in the clause (probably due to phonological reasons). A further phenomenon relates to the weight of the constituents: heavy constituents are likely to be right extraposed, in which case the verb does not appear sentence-finally. The influence of pragmatic factors on the position of the verb is clear in V-initial sentences with finite verbs. These sentences are contextually restricted: they are used in order to introduce new referents in discourse. Further phenomena may also influence the verb position, in particular the discourse properties of postverbal material, however the small number of observations does not allow for empirically justified conclusions.

\subsection{Themes and Locatives}

The crucial question is what determines the variation between the theme and the locative. The data presented in Table 1 shows a general preference for the order theme-locative, which arguably reflects the canonical word order in this language. The proportions of the two alternative orders in our data $(73.1 \%$ Theme-first; 26.9\% Locative-first) are similar to the proportions reported in PINKSTER (1990a:

72 ) for the arguments of transitive verbs $(68.4 \% \mathrm{~S} \prec \mathrm{O}$ and $31.7 \% \mathrm{O} \prec \mathrm{S}$ orders).

It is known that word order in Latin is determined by information structure (see PINKSTER 1990a). A straightforward heuristics for the observation of information structural effects is the discourse status of the referents. As introduced in Section 3.3, we distinguish between new and given referents in context. This binary distinction gives four logically possible permutations for the two constituents at issue. Some locative constructions appear out of the blue, i.e., the discourse status of both referents is new, as exemplified in (17a). Another possibility is a configuration 'new theme and given locative'. This configuration appears in utterances that introduce a new referent in discourse, see (17b). In this example, the asserted information is not the location of the theme referent, but the existence of the theme within the presupposed location. The configuration 'given theme and new locative' is very frequent in texts, however in most cases these sentences do not have a subject constituent (see discussion in Section 3.2). The given subject is overtly encoded only in contexts in which it cannot be uniquely identified as such through the context. An instance is illustrated in (17c): Caesar is a given referent but not the topic of the preceding text. Finally, the configuration of two given referents is illustrated in (17d), which involves anaphoric expressions both for the theme as well as for the locative constituent. The frequencies of these four configurations in text are presented in Table 2. Three types of syntactic construction are distinguished: (a) complements of static verbs (b) complements of motion verbs, and (c) adjuncts. 
(17) a. Erat a septentrionibus collis, ...

'There was, on the north side, a hill, ...' (CAESAR, De bello gallico, VII.83)

b. Context: '... This position fortified one side of his camp by the banks of the river ${ }_{i}$, rendered the country which lay in his rear secure from the enemy (...).'

In eo $o_{\mathrm{i}}$ flumine pons erat.

'Over that river was a bridge.' (CAESAR, De bello gallico, II. 5)

c. Context: '... When they were routed, the townsmen, again intimidated, arrested those persons by whose exertions they thought that the mob had been roused, and brought them to Caesar, and surrendered themselves to him.'

Quibus rebus confectis, Caesar ad oppidum Avaricum, quod erat maximum munitissimumque in finibus Biturigum atque agri fertilissima regione, profectus est, ...

'When these affairs were accomplished, Caesar marched to the Avaricum, which was the largest and best fortified town in the territories of the Bituriges, ...' (CAESAR, De bello gallico, VII.13)

d. Ipse de quarta vigilia eodem itinere quo hostes ierant ad eos contendit...

'He himself during the fourth watch, hastens to them by the same route by which the enemy had gone...' (CAESAR, De bello gallico, I.21) 


\begin{tabular}{|c|c|c|c|c|c|c|c|c|}
\hline & \multicolumn{2}{|c|}{$\begin{array}{l}\text { complement } \\
\text { of static V }\end{array}$} & \multicolumn{2}{|c|}{$\begin{array}{l}\text { complement } \\
\text { of motion } \mathrm{V}\end{array}$} & \multicolumn{2}{|c|}{ adjunct } & \multicolumn{2}{|c|}{ Total } \\
\hline & $n$ & $\%$ & $n$ & $\%$ & $n$ & $\%$ & $n$ & $\%$ \\
\hline \multicolumn{9}{|c|}{ The $=$ new \& Loc $=$ new } \\
\hline The $\prec$ Loc & 3 & 42.9 & 36 & 85.7 & 15 & 68.2 & 54 & 76.1 \\
\hline Loc $\prec$ The & 4 & 57.1 & 6 & 14.3 & 7 & 31.8 & 17 & 23.9 \\
\hline Total & 7 & 100 & 42 & 100 & 22 & 100 & 71 & 100 \\
\hline \multicolumn{9}{|c|}{ The $=$ new $\&$ Loc $=$ given } \\
\hline The $\prec$ Loc & 7 & 31.8 & 30 & 68.2 & 4 & 15.4 & 41 & 44.6 \\
\hline Loc $\prec$ The & 15 & 68.2 & 14 & 31.8 & 22 & 84.6 & 51 & 55.4 \\
\hline Total & 22 & 100 & 44 & 100 & 26 & 100 & 92 & 100 \\
\hline \multicolumn{9}{|c|}{ The $=$ given $\&$ Loc $=$ new } \\
\hline The $\prec$ Loc & 22 & 91.7 & 45 & 95.7 & 9 & 69.2 & 76 & 90.5 \\
\hline Loc $\prec$ The & 2 & 8.3 & 2 & 4.3 & 4 & 30.8 & 8 & 9.5 \\
\hline Total & 24 & 100 & 47 & 100 & 13 & 100 & 84 & 100 \\
\hline \multicolumn{9}{|c|}{ The $=$ given $\&$ Loc $=$ given } \\
\hline The $\prec$ Loc & 16 & 76.2 & 49 & 87.5 & 11 & 78.6 & 76 & 83.5 \\
\hline Loc $\prec$ The & 5 & 23.8 & 7 & 12.5 & 3 & 21.4 & 15 & 16.5 \\
\hline Total & 21 & 100 & 56 & 100 & 14 & 100 & 91 & 100 \\
\hline Grand Total & 74 & & 189 & & 75 & & 338 & \\
\hline
\end{tabular}

Table 2. The order of theme and locative constituents

The influence of discourse status on the word order can be observed in the last column of Table 2. The largest proportion of Locative-first sentences is found in the condition 'new theme and given locative' (55.4\%). This finding is not surprising since it is exactly in this condition that the lower constituent (the locative) outranks the higher constituent (the theme) in the givenness hierarchy.

Furthermore, Table 2 shows an asymmetry depending on the syntactic construction, which is summarized in (18). The tokens involving a preceding locative constituent are 36 out of 75 adjuncts (48\%), 26 out of 74 complements of static verbs (35.1\%), and 29 out 189 complements of motion verb (15.3\%). The comparisons in (18) are significant $\left.\chi^{2}(2)=32.3, p<.001\right)$; however, breaking down this result to its components, we observe that the difference between adjuncts and complements of static verbs does not reach the significance level, while the difference between complements of static verbs and complements of verbs of motion is statistically significant $\left(\chi^{2}(1)=12.6, p<.001\right)$. Hence, only the second asymmetry in (18) is statistically justified.

(18) Proportions of Locative-first orders:

adjuncts $>$ complements (static) $>$ complements (motion) 
The result of the chi-square tests indicates that the crucial distinction is not the syntactic relation (complement vs. adjunct), but the semantics of the verbal head (non-motion vs. motion). Odds ratios indicate that complements of static verbs are 3 times more likely to be fronted than complements of motion verbs and adjuncts are 5.1 times more likely to be fronted than complements of motion verbs (while adjuncts are 1.7 times more likely to be fronted than complements of static verbs). The crucial question is where this difference comes from. Do the syntactic constructions at issue have an influence on word order that is independent from information structure or do particular information structural configurations occur more frequently with certain types of syntactic construction?

The second possibility can be straightforwardly tested in the proportions reported in Table 2. Since we know that the information structural configuration that most frequently induces a Locative-first order is the condition 'new theme \& given locative', the plausible hypothesis to test is whether motion verbs occur less frequently in this condition. This hypothesis is descriptively confirmed, as it can be observed in Table 2. In this condition, we find 44 out of 189 tokens with complements of motion verbs $(23.3 \%), 22$ out of 74 tokens with complements of static verbs $(29.7 \%)$, and 26 out of 75 tokens with adjuncts $(34.7 \%)$ - though these differences are not significant $\left(\chi^{2}(2)=3.8, p *\right)$. Furthermore, a comparison of the odds ratios suggests that only a part of the word order frequencies can be explained through the correlation between syntactic construction and information structure. In particular, odd ratios indicate that complements of static verbs are 1.28 times and adjuncts 1.49 times more likely than complements of motion verbs to occur in the 'new theme \& given locative' condition. Hence, the differences in likelihood of particular constructions to occur with certain information structure can only explain a part of the aforementioned differences in the frequency of Locative-first utterances of the different constructions.

This finding suggests that the examined constructions show different word order properties under identical discourse conditions. A four-way loglinear analysis ('syntactic construction' $x$ 'discourse status of the Theme' $x$ 'discourse status of the Locative' $x$ 'word order') reveals a significant highest level interaction effect $\left(\chi^{2}(2)=6.2, p<.05\right)$. In order to understand the sources of this effect, we will break down the results of the three syntactic constructions. The results from the construction with complements of static verbs are plotted in Figure 2. A three-way loglinear analysis reveals that this data ends up with a model that involves the interaction between the 'discourse status of the theme' and the 'word order' $\left(\chi^{2}(1)\right.$ $=19.7, p<.001)$, while the three-way interaction and the interaction between 'discourse status of the locative' and 'word order' can be removed from the model without significant loss of information. I.e., there is evidence that the discourse status of the theme constituent significantly influences word order with static verbs. 


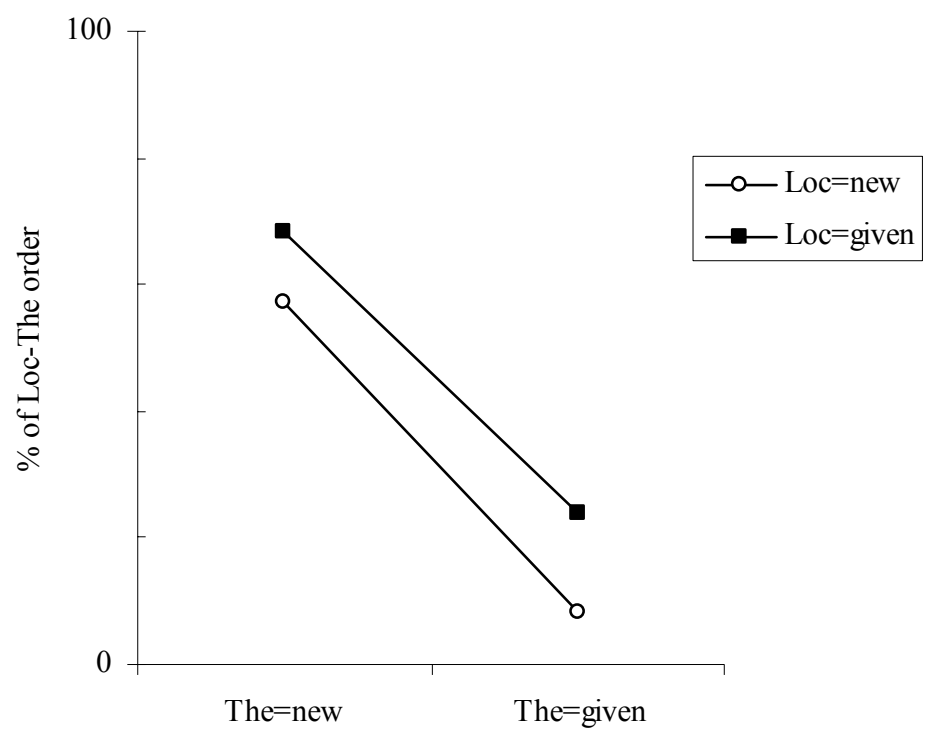

Figure 2. Influence of discourse status on the complements of static verbs

The results from the construction with complements of motion verbs are plotted in Figure 3. The loglinear analysis reveals that the three-way interaction is not significant but the embedded interactions of discourse status are both significant: 'discourse status of the theme' and 'word order' $\left(\chi^{2}(1)=7.7, p<.001\right)$ and 'discourse status of the locative' and 'word order' $\left(\chi^{2}(1)=5.4, p<.05\right)$. Hence, this data reveals that a preference for given constituents to be preposed that holds for themes and locatives independently. Comparing this data with the findings from static verbs, we observe that the data patterns are similar but the size of the effects of discourse status on word order is generally lower for verbs of motion. The independent effects of the theme and the locative are descriptively available both in Figure 2 and Figure 3, though they reach significance only in the latter case. 


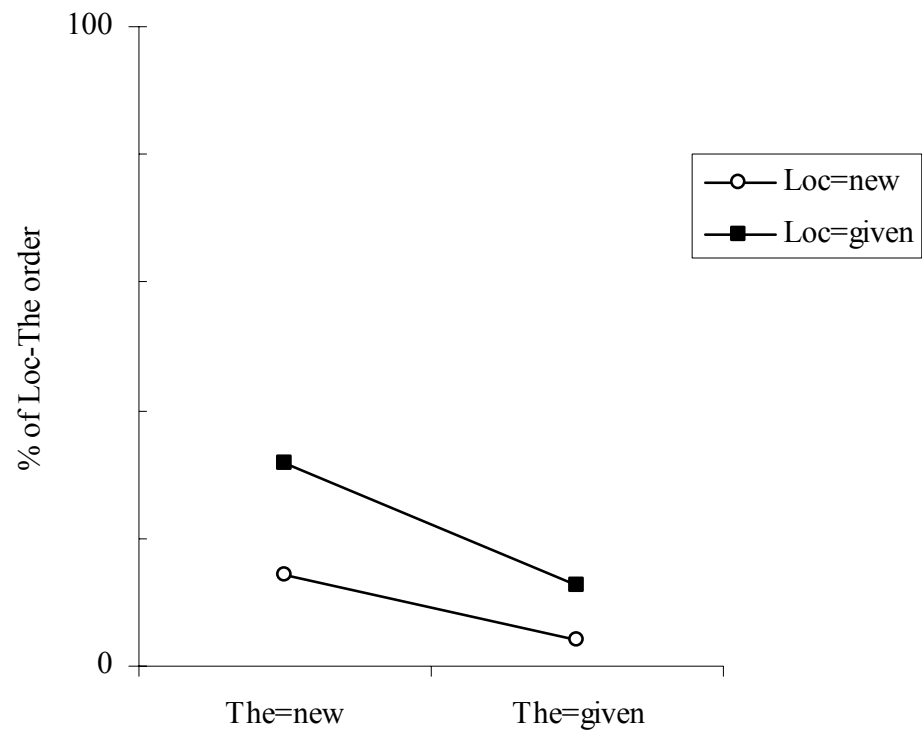

Figure 3. Influence of discourse status on the complements of motion verbs

Finally, Figure 4 plots the findings from adjunct constituents. The loglinear analysis reveals a significant three-way interaction effect $\left(\chi^{2}(2)=7, p<.01\right)$. The source of this interaction can be observed in Figure 4. It is a particular combination of the discourse status of the theme and the discourse status of the locative that induces a substantial increase of the Locative-first orders, i.e., the configuration with a given locative and a new theme. This result is in line with the given-new principle: deviations from the unmarked word order are particularly frequent, iff the lower constituent (locative) outranks the higher constituent (theme) in givenness. 


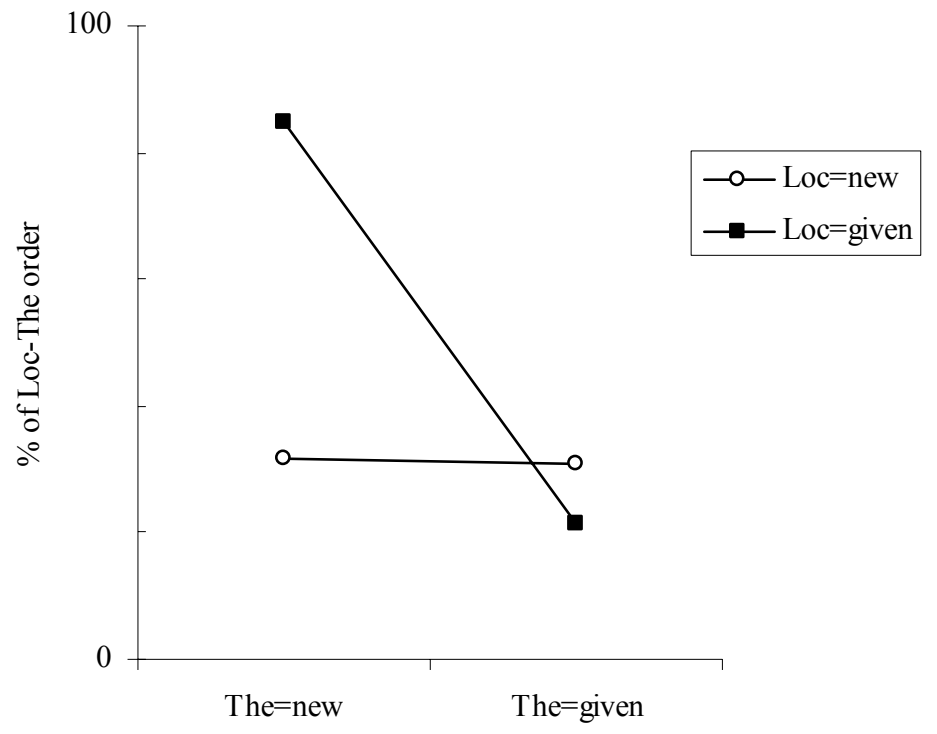

Figure 4. Influence of discourse status on adjuncts

\subsection{Discussion}

The crucial finding of the empirical study reported in 4.1 and 4.2 is the impact of the syntactic construction on word order. The differences we observe in Latin cannot be reduced to syntactic distinctions (as has been done for related phenomena in English, see BRESNAN 1994: 75-77, 82f., REINHART 1983: 68-72). There is no clear evidence that locative complements and locative adjuncts have a different canonical position (KÜHNER and STEGMANN 1976: 613 and DEVINE and STEPHENS 2006: 79 assume for both types of locatives that they occupy a preverbal position; however, it should be clear that the evidence for such statements is the observation of preferences in a language with great word order flexibility). We may speculate that complements are less likely to occur in a position at the left periphery of the clause, since they are more tightly related to the event than adjuncts (see a similar observation concerning the complements of motion verbs in DEVINE and STEPHENS 2006: 93). This difference can account for the fact that the overall proportion of marked orders with locative adjuncts is (descriptively) greater than the proportion of marked orders with complements, see (18). Note that the locative adjuncts in our sample contain event-external and event-internal adjuncts (the former modifying the entire event, while the latter modifying a part of it). The high amount of Locative-first orders independently of the discourse status may be due to the proportion of event-external adjuncts that preferably do not intervene between the subject and the predicate. The significant higher order interaction in Figure 4 results from the fact that these adjuncts are more likely to occur in the left periphery than in the right periphery of the clause, when they are part of the contextually given information (and the subject does not). 
The challenging result is the difference between static verbs and verbs of motion. This finding cannot be explained in syntactic terms, since the locative constituent is governed by the verb in both cases. As already discussed in Section 4.2, we observe two differences between Figure 2 and Figure 3: (a) the influence of the discourse status of the locative is available in both verb groups but only reaches significance in the data from motion verbs; (b) the proportion of Locative-first orders is generally lower with motion verbs than with static verbs.

There are no independent reasons that can account for the difference in (a). Empirically, the result of the chi-square test indicates that there is not enough evidence to reject the null-hypothesis that the discourse status of the locative does not have an influence on the word order of static verbs; this outcome can also result from the fact that we examined 2.5 times more tokens of motion verbs than tokens of static verbs, hence this finding does not allow for strong conclusions.

The difference between the proportions of Locative-first orders is a statistically justified result (see Section 4.2). This difference in the sample from Classical Latin is reminiscent of the observations of BIRNER (1994: 254, 1995), who reports that the majority of the tokens of inversion in English involve a verb that is not part of the asserted information (i.e., either the verb to be or a verb that is familiar in discourse). This is the case in our data: the 74 tokens of static verbs involve 25 sentences with the verb esse; in the Locative-first order, we find 15 tokens of the verb esse $(60 \%)$ and 11 tokens of lexical verbs $\left.(22.4 \%)\left(\chi^{2}(1)=10.2, p<.002\right)\right){ }^{11}$

Since syntax does not account for the facts, we should search for an explanation in the interaction between the semantic contribution of the verb and information structural properties. The data reported in Section 4.2 refer to the discourse status (given vs. new) of the theme and the locative constituent, but there is no evidence (and no reason to assume) that Latin word order directly encodes discourse status. Word order reflects the choice of a particular linearization of the propositional content, which is a means to establish information structural domains such as topic or focus that can be phrased together in the phonological realization of the utterance. What the speaker selects in discourse is an information structure, which can be optimally realized through a particular linearization (see a similar view in terms of aboutness in HÖRNIG and WESKOTT 2010: 374). The observed influence of discourse status on word order is the indirect product of the preferences for a certain discourse status to occur in a particular information structural domain, e.g., the preference for a given referent to be the topic of an utterance. In order to get a better estimation of the influence of the discourse status to the linearization, we have to consider the contribution of the verb.

Existential verbs such as esse 'to be' do not have any contribution to the propositional content. Consequently, this verb is not part of the asserted information anyway. The dataset of static verbs contains a large proportion of this verb (33.8\%); we may hypothesize that this subset shows the pure effect of the

${ }^{11}$ Note, furthermore, that the difference in the locative-first orders is independent of the position of the existential verb. 
discourse status of the two involved participants, the theme and the locative constituent. A configuration with a given locative and a new theme is very likely to be an expression that introduces a new discourse referent; the domain of asserted information is the theme, which is optimally realized after the given locative that links the utterance to the previous discourse (see (17b) repeated below as (19)).

(19) Context: '.. This position fortified one side of his camp by the banks of the river $_{i}$, rendered the country which lay in his rear secure from the enemy (...).'

In eo $o_{\mathrm{i}}$ flumine pons erat.

'Over that river was a bridge.' (CAESAR, De bello gallico, II. 5)

Motion verbs encode together with the locative constituent an event of motion. We assume that this event of motion is typically the asserted information of the utterance, and this holds independently of the discourse status of the localized object. Consider the information structure of the utterance in (20). The participants of the locative relation have the same discourse status as in (19): 'new theme and given locative'. However, the given locative ad eum is part of the predicate ad eum pervenit 'he came to him'. Independently of the givenness of the locative, the predicate is the asserted information of the clause. The theme-locative-verb order suggests that the speaker proceeds as follows. First, he introduces the new theme through a sentence-initial topic phrase. The predicate ad eum pervenit is a further domain of new information that stands in a relation of aboutness to the just introduced discourse referent.

(20) a. Interim Teutomatus, Olloviconis filius, rex Nitiobrigum, ... ad eum pervenit.

'In the meantime, Teutomarus, the son of Ollovicon, the king of the Nitiobriges, ... came to him.' (CAESAR, De bello gallico, VII.31)

The difference between static and motion verbs with respect to the frequencies of word orders in Section 4.2 can be accounted for, if we assume that motion verbs are more likely to be part of the asserted information than static verbs (including a substantial portion of the existential esse).

\section{Conclusions}

This article presented a corpus study on the word order properties of locative constructions in Classical Latin. The empirical findings confirmed previous observations that Latin word order involves considerable freedom that is mainly determined by information structure. The verb in CAESAR is predominantly clausefinal allowing for deviations that are either determined by structural factors (e.g., 
fronting of light verbs) or by information structure (for instance, V-initial presentational constructions).

The order of the referents of a locative construction is influenced by their discourse properties, but crucially also depends on the properties of the syntactic construction. Apart from the difference between the ordering preferences for adjuncts and complements, we identified a difference in the word order properties of static verbs and verbs of motion. We have argued that this difference can be drawn back to the semantic contribution of the two verb classes to the propositional content. This explanation is based on a difference that is beyond the properties of the spatial relation (static vs. dynamic) as well as the syntactic difference between complements of motion verbs and complements of existential verbs. The crucial issue is the contribution of the verb to the propositional content and the corresponding likelihood of it to be part of the asserted information (compare BIRNER 1994: 254, 1995 on English).

\section{References}

ADAMS, J. N. (1976): A typological approach to Latin word order. Indogermanische Forschungen 81, 70-99.

Albrecht, Michael Von (1994): Geschichte der römischen Literatur: Von Andronicus bis Boethius, Bd. 1 [2. Auflage]. München: Saur.

ArRegi, KARLOS (2001): Focus and word order in Basque. Ms., MIT.

Bauer, Brigitte L. M. (2009): Word order. In: Baldi, Philip and Pierluigi Cuzzolin (eds.), New perspectives on historical Latin syntax 1: Syntax of the sentence. Berlin/New York: Mouton De Gruyter, 3-35.

BIRNER, BETTY J. (1994): Information status and word order: An analysis of English inversion. Language 70.2: 233-259.

BIRNER, BETTY J. (1995): Pragmatic constraints on the verb in English inversion. Lingua 97: 233256.

Bolkestein, A. MAChtelt (1989): Parameters in the expression of embedded predications in Latin. In: Calboli, Gualtiero (ed.), Subordination and other topics in Latin. Amsterdam/Philadelphia: Benjamins, 3-35.

BRESNAN, JOAN (1994): Locative inversion and the architecture of universal grammar. Language 70.1, $72-131$.

ChARPIN, FrançoIs (1977): L'idée de phrase grammaticale et son expression en latin. Paris: Champion.

ChARPIN, FrAnÇOIS (1989): Étude de syntaxe énonciative: l'ordre des mots et la phrase. In: CALBOLI, GUALTIERO (ed.), Subordination and other topics in Latin. Amsterdam/Philadelphia: Benjamins, 503-520.

DE Jong, JAN R. (1989): The position of the Latin subject. In: CAlboli, Gualtiero (ed.), Subordination and other topics in Latin. Amsterdam/Philadelphia: Benjamins, 521-540.

Del Vecchio, Tommaso (1989): Observations sur l'ordre des mots dans le latin archaique. In: CAlboli, Gualtiero (ed.), Subordination and other topics in Latin. Amsterdam/Philadelphia: Benjamins, 541-558.

Du BoIs, JOHN W. (1987): The discourse basis of ergativity, in: Language 63.4, 805-855.

Devine, A. M. and Laurence D. Stephens (2006): Latin word order: Structured meaning and information. Oxford: Oxford University Press.

Elerick, CHARles (1989): Gapping, preemptive markedness, and word order in Latin. In: CALBOli, GuAltiero (ed.), Subordination and other topics in Latin. Amsterdam/Philadelphia: Benjamins, 559-571.

Féry, CAROline, Stavros Skopeteas, and Robin HÖRnig (2010): Cross-linguistic comparison of 
prosody, syntax and information structure in a production experiment on localizing expressions. Transactions of the philological society 109, 1-23.

GREEN, J. (1908/1909): How far does the word-order in Latin indicate the proper emphasis? The Classical Weekly 2, 2-4 and 10-13.

Hofmann, Johann BAPTIST and ANTON SzAnTyr (1965): Lateinische Syntax und Stilistik. Munich: Beck.

HöRNIG, RoBIN and CAROLINE FÉRY (2009): Linguistic markers of discourse status in describing altered spatial layouts. Ms., University of Potsdam.

HöRNIG, RoBIn, OBERAUER, K., and WeIDENFELD, A. (2005): Two principles of premise integration in spatial reasoning. Memory \& Cognition, 33, 131-139.

HÖRNIG, ROBIN and WeSKOTT, THOMAS (2010): Given and new information in spatial statements. In MALte ZimMERMAN and CAROLINE FÉRY (eds.), Information Structure: Theoretical, typological and experimental perspectives. Oxford: Oxford University Press.

JACKENDOFF, RAY (1983): Semantics and cognition. Cambridge/Mass.; London: MIT Press.

KiliÇASLAN, YiLMAZ (2004): Syntax of information structure in Turkish. Linguistics, 42.4, 717-765.

KLEIN, WolfGANG (1991): Raumausdrücke. Linguistische Berichte 132:77-114.

Koll, HANS-GeORg (1965): Zur Stellung des Verbs im spätantiken und frühmittelalterlichen Latein, in: Mittellateinisches Jahrbuch 2, 241-272.

KÜHNER, RAPHAEL and CARL STEGMANN (1976): Ausführliche Grammatik der lateinischen Sprache, Zweiter Teil: Satzlehre [Fünfte Auflage]. Hannover: Hahnsche Buchhandlung.

LEHMANN, Christian (1979): Zur Typologie des Lateinischen. Glotta 57, 237-253.

Lehmann, Christian (1983): Latin preverbs and cases. In PinKSTER, HARM (ed.), Latin linguistics and linguistic theory: Proceedings of the 1st International Colloquium on Latin Linguistics, Amsterdam, April 1981. Amsterdam, Philadelphia: Benjamins; 145-161.

LeHMANN, CHRISTIAN (1985): Latin case relations in typological perspective. Touratier, Christian (ed.), Syntaxe et latin: Actes du lleme Congres international de linguistique latine, Aix-enProvence, 28-31 Mars 1983. Aix-en-Provence: Universite de Provence.

Lehmann, Christian (1992): Yukatekische lokale Relatoren in typologischer Perspektive, in: Zeitschrift für Phonetik, Sprachwissenschaft und Kommunikationsforschung 45, 626-641.

LEHMANN, CHRISTIAN (1998): Regiones espaciales en perspectiva tipológica, in: GarcíaHeRnÁNDEZ, BENJAmín et al. (eds.), Estudios de lingüistica latina. Actas del IX Coloquio Internacional de Lingüistica Latina, Universidad Autónoma de Madrid, 14-18 de abril de 1997. Madrid: Ediciones Clásicas, 455-466.

LeVInSON, StePHEN (2003): Space in language and cognition. Cambridge: Cambridge University Press.

Linde, P. (1923): Die Stellung des Verbs in der lateinischen Prosa, in: Glotta 12, 153-178.

LURAGHI, SILVIA (1995): Verb-initial sentences in some ancient Indo-European languages. In PAMELA Downing and Michael Noonan (eds.), Word order in discourse. Amsterdam: Benjamins, 355-386.

Marouzeau, Jules (1938): L'ordre des mots dans la phrase latine, Tome II: Le verbe. Paris: les belles lettres.

MarouZeAu, Jules (1949): L'ordre des mots dans la phrase latine, Tome III: Les articulations de l'énoncé. Paris: Champion.

Menge, Hermann (2005): Lehrbuch der lateinischen Syntax und Semantik. [2. Auflage, 1=2000]. Darmstadt: Wissenschaftliche Buchgesellschaft.

PANHUIS, DiRK (1980): Gapping in Latin, The Classical Journal 75(3), 229-241.

PANHUIS, DiRK (1982): The Communicative perspective in the sentence: A study of Latin word order. Amsterdam: Benjamins.

PinkSTER, HARM (1990a): Evidence for SVO in Latin? in: Wright, R. (ed.), Latin and the Romance languages in the Early Middle Ages, London: Routledge, 69-82.

PINKSTER, HARM (1990b): Latin Syntax and Semantics. London: Routledge.

PinKSTER, HARM (1995): Word order in the Late Latin: Gesta conlationis carthagiensis. In: CALLEBAT, LoUIS (ed.), Latin vulgaire - latin tardif IV: actes du 4e colloque international sur le latin vulgaire et tardif, Caen 2-5 septembre 1994. Hildesheim: Olms, 549-560.

ReINHART, TANYA (1983): Anaphora and semantic interpretation. London: Croom Helm. 
RosÉn, HANNAH (1991): The definite article in the making, in: HERMAN, JÓZSEF (ed.), Linguistic studies on Latin: Selected papers from the $6^{\text {th }}$ international colloquium on Latin linguistics (Budapest, 23-27 March 1991). Amsterdam/Philadelphia: Benjamins, 129-150.

Ross, JOHN ROBERT (1970): Gapping and the order of constituents, in: MANFRED BIERWISCH and Karl Heidolph (eds.), Progress in linguistics. The Hague: Mouton, 249-259.

RubenBAuer, HANS and J. B. HofMANN (1995): Lateinische Grammatik (neubearbeitet von R. HeINE) [12. Auflage, 1= 1975]. C. C. Buchners, J. Lindauer, and R. Oldenbourg: Bamberg, München.

SCHLICHER, J.J. (1936): The development of Caesar's narrative style. Classical Philology 31, 212-224.

Skopeteas, Stavros and Gisbert Fanselow (2010): Focus in Georgian and the expression of contrast. Lingua 120, 1370-1391.

Somers, MAARTJE H. (1991): Theme and topic: The relation between discourse and constituent fronting in Latin, in: HeRMAN, JózSEF (ed.), Linguistic Studies on Latin: Selected Papers from the $6^{\text {th }}$ international colloquium on Latin linguistics (Budapest, 23-27 March 1991). Amsterdam/Philadelphia: Benjamins, 151-163.

SPEVAK, Olga (2008): The position of focus constituents in Latin: A comparison between Latin and Czech. Journal of Pragmatics 40, 114-126.

SpevaK, Olga (2010): Constituent order in Classical Latin prose. Amsterdam/Philadelphia: Benjamins.

TALMY, LEONARD (1985): Lexicalization patterns: semantic structure in lexical forms, in: SHOPEN, Тімотну (ed.), Language typology and syntactic description. Vol. III: Grammatical categories and the lexicon. Cambridge: Cambridge University Press, 57-149.

Talmy, Leonard (2000): Toward a cognitive Semantics: Volume I: Concept Structuring Systems. Cambridge/Mas. and London: MIT Press.

TOURATIER, Christian (1994): Syntaxe Latine. Louvain-La-Neuve: Peeters.

WALKER, ARTHUR T. (1918): Some facts of Latin word order. The Classical Journal 13(9), 644-657.

STAVRos SKopetEAS

Universität Bielefeld

Postfach 100131

33501 Bielefeld

(stavros.skopeteas@uni-bielefeld.de) 